\title{
Conversation Analysis of Boke-tsukkomi Exchange in Japanese Comedy
}

Hideo Tsutsumi

The University of New South Wales

\begin{abstract}
This article analyses and discusses what Japanese comical exchange called boke-tsukkomi is like and how it draws laughter. Conversation analysis and incongruity resolution are used as methods for the examination of the boke-tsukkomi examples. This paper will lend itself to further research on the dyadic exchange in the cross cultural context.
\end{abstract}

\section{Keywords}

boke-tsukkomi, manzai, comedy, CA (Conversation Analysis), IR (Incongruity Resolution)

\section{Introduction}

This paper will analyse and discuss the Japanese comedy exchanges called boketsukkomi. Boke-tsukkomi exchange is a comical verbal battle of words and worldviews between the boke player and the tsukkomi player. ${ }^{1}$ Boke literally means "vagueness" and tsukkomi "to poke". The boke is characterized by his/her out-of-context remarks and the tsukkomi by his/her sharp responses to bring back their twisted dialogue to social order. Boke and tsukkomi are generally translated as "the fool or funny man" and "the sharp man or straight man" respectively. The funny man is defined as 'a man whose job is to entertain people by telling jokes.' The straight man is 'a member of a comedy team who feeds lines to a partner who in turn replies with usually humorous quips. ${ }^{3}$

This paper will be concerned with the typical verbal exchanges of boke-tsukkomi and the straight man and the funny man, as defined above, but not with what their designated roles say or do in their actual performance. For example, the straight man, Bud Abbott, in Abbott and Costello in their famous wordplay routine Who's on First does not feed any lines to his partner funny man Costello, but it is Abbott himself who fools

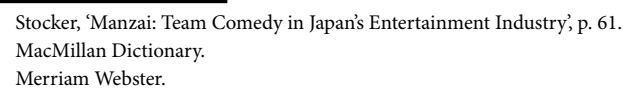


Costello by calmly repeating jokey baseball player's names, such as the first baseman called Who, as in the following example: ${ }^{4}$

Costello: Well, then who's playing first?

Abbott: Yes.

Costello: I mean the fellow's name on first base.

Abbott: Who.

We will also look at the exchange of boke and tsukkomi, and the straight and the funny as adjacency pairs using terminology from conversation analysis (henceforth CA). These pairs then will be examined through the techniques of CA.

The paper will first look into what the exchange of boke-tsukkomi in Japanese is like in relation to that of the straight man and the funny man in English. Next, how the boke-tsukkomi exchanges cause laughter will be analysed. Lastly, seven types of tsukkomi utterances that Abe claims ${ }^{5}$ exist will be illustrated. Throughout the paper, incongruityresolution theory (henceforth IR) will be referred to, which is also displayed in the Funniness Structure Model. ${ }^{6}$ In order to support the analysis of the tsukkomi lines, superiority theory will also be mentioned.

As a pilot study, this paper seeks to lend itself to further research projects investigating boke-tsukkomi exchanges in English contexts. As a preliminary investigation, a recording of stand-up comedy constructed of the boke-tsukkomi exchanges is partly transcribed and studied at the end of this paper. The author and his friend performed this Japanese style of comedy in English in front of the Englishspeaking audience.

\section{Literature Review}

Stocker ${ }^{7}$ states that the friendly antagonism of boke and tsukkomi characterise manzai team comedy in Japan which is usually said to reflect the distinctive characteristics of the ordinary people in the urban Osaka area. Today's manzai is generally based on shabekuri manzai - chatty manzai between boke and tsukkomi, which dates back to the 1930s. ${ }^{8}$

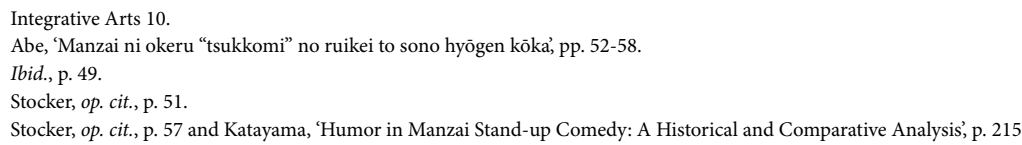


As boke and tsukkomi are different roles, so are their utterance types. Ōshima ${ }^{9}$ explains that ' $(\mathrm{t})$ he boke's role is to make stupid or out-of-context statements and to engage in cognitive misunderstandings', whereas the tsukkomi role '...involves making statements to correct or to put down the boke.

CA has its main interests in the context but not the structure of jokes; however, it has great potential to illuminate some significant aspects of humor. ${ }^{10}$ Partington ${ }^{11}$ makes clear the difference between conversational laughter and humorous laughter: the former is mundane, requires intimate contact and speakers actually laugh more than audiences do, ${ }^{12}$ while the latter is based on jokes, comedians are physically and socially distant and typically they will not laugh. As the aim of this study is to find out what is humorous in boke-tsukkomi stand-up comedy, its focus will be confined to the latter: humorous laughter. In the CA research into laughter, Glenn ${ }^{13}$ says that laughter has its meaning in its placement in the sequence, which comprises its referent, the laughable, and the following laughter itself, therefore, the laughter is indexical. Consequently, the jokes can be judged if they are funny or not by seeking out their indexical sign: the subsequent laughter. This pair i.e. a laughable utterance and its subsequent laughter is further said to form an adjacency pair. ${ }^{14}$ In addition, the last two exchanges of joking interaction before its laughter also form an adjacency pair comprising a serious utterance which can be the joking material and a nonserious utterance which is the joke itself. ${ }^{15}$

An adjacency pair is a structure which CA views as a basic component of interactions. An adjacency pair is defined as 'a sequence of two utterances, which are adjacent, produced by different speakers, ordered as a first part and second part, and typed, so that a first part requires a particular second part or range of second parts.'. Adjacency pairs in daily interactions are, for example greeting-greeting, questionanswer, request-acceptance/refusal. ${ }^{17}$ The adjacency pairs of the straight and the funny can be said to be comprised of the serious utterance - the nonserious utterance, the setup - the joke or, congruity - incongruity. The boke-tsukkomi adjacency pair, on the other hand, seems to constitute the joke - the criticism, the misunderstanding - the correction or incongruity - resolution. This incongruity - resolution interpretation might be compatible with one of the various boke-tsukkomi exchanging types mentioned by Inoue: ${ }^{18}$ chaos $v$ s. order. Incongruity creates chaos but resolution puts it back into order.

\footnotetext{
Ōshima, 'Rakugo and Humor in Japanese Interpersonal Communication', p. 105.

10 Attardo, 'Linguistic Theories of Humor', pp. 330-331.

Partington, 'The Linguistics of Laughter: A Corpus-Assisted Study of Laughter-Talk', p. 82.

Provine, 'Laughter: A Scientific Investigation', p. 27 cited in Partington op. cit., p. 82.

Glenn, 'Laughter in Interaction', p. 48.

Norrick, 'Conversational Joking: Humor in Everyday Talk', p. 23 and Grindsted, 'Joking As a Strategy in Spanish and Danish Negotiations', p. 168.

Norrick, op. cit., p. 25 and Grindsted, op. cit., p. 165.

Schegloff and Sacks, 'Opening Up Closings', p. 295; also Schegloff, 'Sequencing in Conversational Openings', cited in Schiffrin 'Approaches to Discourse', p. 236.

Wardhaugh, 'An Introduction to Sociolinguistics 4th ed., p. 296.

8 Inoue, 'Manzai: Osaka no warai (Manzai: Osakan Humor)', p. 33, cited in Katayama, op. cit., p. 216.
} 
Usually the second part of the pair is something expected and preferred according to the first part, just as the answer is preferred to hear in response to the question rather than its absence. However, nonserious responses to serious statements or incongruity to congruity would not be preferred unless the participants are in the play frame, or rather in the context where the non-bona fide mode is welcome to enter into the bona fide mode. The bona fide mode is the ordinary mode where there is no lying, acting, joking or etc., while the non-bona fide mode is where what speakers say is not necessarily taken wholly literally or truthfully. ${ }^{19}$ Therefore, the second part of the adjacency pair jokes, can or should be unexpected or dispreferred in order to switch from the bona fide mode into the non-bona fide mode to create the joke.

Furthermore, the second part of an adjacency pair completes the adjacency pair, for example the question-answer adjacency pair cannot be completed without the second part, the answer. ${ }^{20}$ Oshima ${ }^{21}$ and Stocker ${ }^{22}$ state that the tsukkomi's response frames and completes the boke-tsukkomi adjacency pair. In the straight-funny adjacency pair, on the other hand, without the funny man's incongruity the straight-funny adjacency pair will not be completed.

IR 'postulates that humor is created by a multistage process in which an initial incongruity is created, and then some further information causes that incongruity to be resolved. ${ }^{23}$ As to incongruity, Shultz explains in detail 'incongruity is usually defined as a conflict between what is expected and what actually occurs in the joke. ${ }^{24}$ This incongruity will be resolved by reconsidering the first prediction and replacing it with another interpretation brought by the punchline..$^{25}$ Critchley ${ }^{26}$ states that 'in order for the incongruity of the joke to be seen as such, there has to be a congruence between joke structure and social structure - no social congruity, no comic incongruity'. This social congruity might be equal to Shultz's 'what is expected'. The mechanism of IR can be illustrated in the Funniness Structure Model Fig. $1 .^{27}$

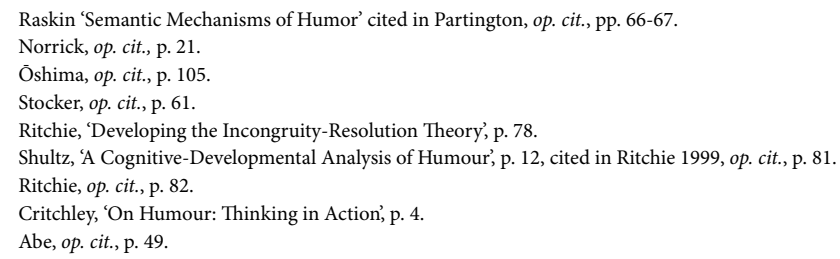




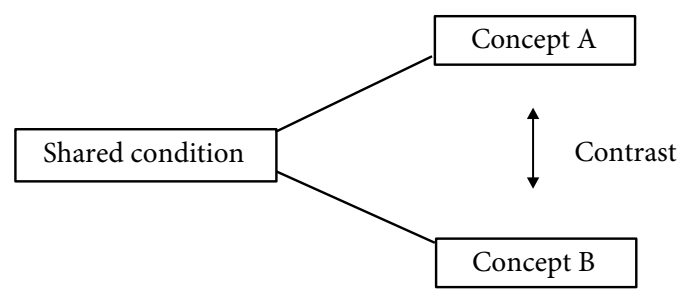

Figure 1: Funniness Structure Model

Both Concept $A$ and Concept $B$ derive from a shared condition. Applying Shultz's definition of IR cited above to this model, Concept $A$ is 'what is expected', Concept $B$ is 'what actually occurs in the joke' and contrast is the 'conflict'. It is Concept $B$ that boke and the funny man usually come up with.

Provided that the audience's expectations are relevant to the topic, funny lines are somewhat irrelevant to it. Regarding less relevant statements, Sperber and Wilson ${ }^{28}$ argue as follows:

Precisely because the processing of (55) (There is a smell of gas) is governed by the search for relevance, assumption (57) (The gas company is not on strike) is unlikely to be made: the processing effort needed to derive (57) is greater than the effort needed to derive (56) (There is a gas leak somewhere in the house), and moreover (57) does not lead to rich contextual effects achievable at a low processing cost.

If these three utterances $(55,56$, and 57$)$ are arranged as follows, they can illustrate not only the parenthesised incongruity mechanism but also the underlined boke-tsukkomi adjacency pair functioning as incongruity - resolution.

$(\mathrm{T}=$ tsukkomi $\mathrm{B}=$ boke $)$

1. T: Hey, there is a smell of gas. (Shared condition)

2. B: Yeah, the gas company is not on strike. (Concept $B$ )

3. T: You idiot! There is a gas leak somewhere in the house! (Concept A)

28 Sperber and Wilson, 'Relevance: Communication and Cognition 2nd ed.', p. 152. 
We can infer two things from this example: 1) boke line 2 avoids the "immediate" relevance, and 2) recipients on the other hand need to take more time and effort to understand the less relevant assumption. Sperber and Wilson ${ }^{29}$ state, ' $(\mathrm{t})$ he construction and processing of different assumptions will involve different effects and amounts of effort, and hence different degrees of relevance.' Thus if the tsukkomi's more relevant line 3 highlights the boke's less relevant line 2, it would help the audience process that less relevant assumption, subsequently resolving the incongruity.

An example disputing IR theory is where the audience waits for their favourite comedian Martin Allen's catch phrase Hello dere, and laughs at him. ${ }^{30}$ The reason why his Hello dere causes laughter would be because of the way he says it every time he, as a funny man, appears on the stage.

And also not all incongruous utterances can draw laughter. For example, after someone greets you with Hey dude, you start singing Let it be... instead of Hey Jude.... Both Hey Jude and Let it be are incongruent but Let it be is so unconnected that it cannot be resolved. Hey Jude, however, can be resolved by means of a pun. Therefore in order to explain humor, IR is not a single monolithic theory and it also needs complementary accounts like the pun to describe a joke.

Superiority theory is another such theory and will help explain the effect of tsukkomi when IR theory would not be able to entirely explain it. Superiority theory dates back to Plato saying 'people laugh at what is ridiculous in their friends. ${ }^{31}$ Aristotle ${ }^{32}$ maintains that:

Comedy... is a representation of inferior people, not indeed in the full sense of the word bad, but the laughable is a species of the base or ugly. It consists in some blunder or ugliness that does not cause pain or disaster, an obvious example being the comic mask which is ugly and distorted but not painful.

Thus people might have a tendency to laugh at stupidity or inferiority of someone out of a sense of superiority. The adjective stupid is defined as 'lacking in common sense or intelligence. ${ }^{33}$ However, stupid utterances heard in comedies should be created by intentional misunderstanding of the foregoing context. ${ }^{34}$ Thus

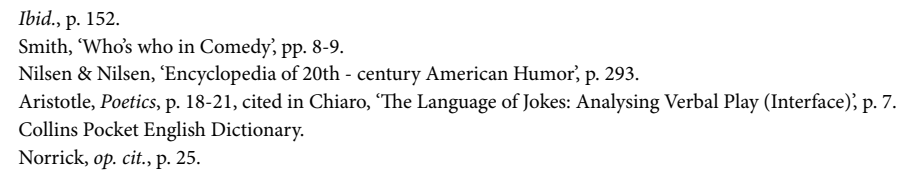


the recipients of the jokes would laugh at the intentional stupidity of the boke or the funny man, who can therefore be regarded as highly-intellectual rather than genuinely stupid in reality.

$\mathrm{Abe}^{35}$ claims that there are seven types of tsukkomi in two categories (the name of each type and category is translated by the author). One category is 'call of attention' in which the tsukkomi line adds no comment on the incongruous boke line but only calls the audience's attention towards it. The other category is 'comment on content' in which the tsukkomi line adds some comment on the incongruous boke line. 'Call of attention' includes 1) 'negation', 2) 'echo' and 3) 'silence', while 'comment on content' involves 4) 'correction', 5) 'derivation', 6) 'metaphor' and 7) 'negative reflection. Each type is illustrated with the examples later.

\section{Data and Methodology}

The data come from various sources in both Japanese and English and in both written and spoken modes. The sources are as follows: a book Nihon Bungakusha Hentairon: Bakushō Mondai (Japanese Literary People Perversion-ology [= study of perversion]) ${ }^{36}$ which contains the transcript of a comedy duo Bakushō Mondai's boke-tsukkomi dialogue on Japanese literary people, a book Who's who in Comedy ${ }^{37}$ which cites some transcripts of comedians' routines, and an Internet website YouTube which holds many comedy video clips. Such audio-visual data are restricted to the boke-tsukkomi exchanges so that the paper can pursue its discussion beyond their structure: their humorous elements. Therefore, the straight-funny data are all in the reading text only to compare their structure with that of boke-tsukkomi. All the Japanese examples are transcribed in Roman characters and also the author's English translation is provided. Video clips from YouTube are cited with their titles and durations. The contributor's screen names are listed in the footnotes. More details including the retrieved date and URL can be found in the list of references.

As the preliminary step for CA, the co-text details of the data will be provided below. The settings in the video clips are at public theaters or the like, and the participants are the comedians and audiences. In the reading text, unfortunately, the settings and participants, i.e. readers and writers cannot be observed. Lengths of the extracted interactions range from 7 to 11 seconds or from 3 to 10 lines, which are restricted to the optimum stretch to argue the main points. Relationships between the

\footnotetext{
35 Abe, op. cit., pp. 52-58.

36 Bakushō Mondai, 'Nihon Bungakusha Hentairon (Japanese Literary people Perversion-ology)'.

37 Smith, op. cit.
} 
participants are unknown but, considering the settings, the audiences and readers would be mostly strangers to the comedians but know of them through multimedia e.g. TV. The comedians are males in both reading and audio-visual examples. Their audiences and readers are unknown but they would be both male and female, and most of them should be old enough to be able to find the comedians' jokes funny as their laughter is heard at least in the video data.

Points of the discussion are fairly restricted to IR due to time and word constraints although there are many other factors in drawing laughter such as regional accents and cultural values. Unlike these two points, IR appears to travel across languages and cultures as seen in the comparison between boke-tsukkomi and straightfunny exchanges in the next section.

Although the analysis concentrates on the language, gestures inevitably communicate messages to the audiences in the visual data. Such visual signs are, therefore, parenthesised and inserted into the relevant places in the transcribed text, for example (feeling his crewcut head with his hand) in Ex. 4.

Furthermore, all the utterances in the boke-tsukkomi and straight-funny exchanges appear to be designed deliberately to provoke laughter. Thus, naturally occurring utterances, which CA is usually concerned with, strictly speaking, seem to be only the audiences' laughter.

The characteristics of the relationship between the audience and their laughter are that they are given a freedom to choose to laugh or not, and also they are in a situation where they are likely to laugh. This is because they all seem to be in the play frame or non-bona fide mode with the comedians and other members in the audience. There is also research supporting this point, which indicates that people are 30 times more likely to laugh when they are with others than when they are alone. ${ }^{38}$ In the audiovisual data the audiences are all in a group, hence there is greater probability of laughter than when in a non-bona fide yet solitary mode (e.g. watching a comedy film alone). They also need not to laugh at unfunny jokes to save the joker's face.

Now we will search the audio-visual data for the audience laughter to pin down the laughables. Identifying the laughables seems to be as simple as keeping track of audience laughter since the laughter occurs upon its referent being recognised, which

38 Provine and Fischer, 'Laughing, Smiling, and Talking: Relation to Sleeping and Social Context in Humans', pp. 295-305, cited in Martin, 'The Psychology of Humor: An Integrative Approach', p. 128. 
can happen both at the completion and while processing the laughable utterance. ${ }^{39}$ Glenn, ${ }^{40}$ further points out that the gap between the laughable and the laughter can constitute evidence of the failure of a laughable. In the data, however, some of the boke's incomplete laughables seem to be deliberately made irresolvable until the following tsukkomi utterance helps it become resolved, rather than to fail halfway through.

Following Abe's ${ }^{41}$ seven types of tsukkomi, examples from YouTube and the author's own experience are provided below. Thus, all of the examples are different from those of Abe, ${ }^{42}$ but designed to illustrate each type as precisely as he claims.

A recording of an English boke-tsukkomi performance by the author and his friend is also transcribed and studied through the CA techniques. The whole length of the recording is 4:23 minutes but the transcribed examples are only a few fragments of it. Its setting is at a one-time event with a temporary stage in a university college. Participants are inexperienced comedians, including the author and his friend. The audience members stay at the college and come to see their college mates' performances. Relationships between the comedians and the audience are closer than acquaintances as the author also stays at the college, although his friend is a visitor who is totally new to the audience. The comedians are both 25 year old Japanese males and the audience is made up of 18-27 year-olds, including both sexes and various races.

\section{Analysis and Discussion}

First of all, the structure of the boke-tsukkomi exchange in comparison with the straightfunny exchange will be analysed. The examples used in this analysis are extracted from the reading materials. Secondly, the way the boke-tsukkomi exchange draws laughter will be illustrated by looking into three examples from the audio-visual data. Thirdly, the tsukkomi types proposed by $\mathrm{Abe}^{43}$ will be illustrated in the examples the author collected. Finally, the boke-tsukkomi exchanges the author and his friend performed in English will be examined and discussed.

39 Jefferson, Sacks, and Schegloff, 'Preliminary Notes on the Sequential Organization of Laughter', p. 12; Schenkein, 'Towards an Analysis of Natural Conversation and the Sense of Heheh', p. 365; Jefferson, 'Notes on the Sequential Organization of Laughter in Conversation; Onset Sensitivity in Invitations to Laugh' p. 7; Sacks, 'An Analysis of the Course of A Joke's Telling in Conversation', p. 348, cited in Glenn, op. cit., p. 48.

40 Ibid., p. 48

41 Abe, op. cit., pp. 52-58.

42 Ibid., pp. 52-58.

43 Ibid., pp. 52-58. 
Boke-tsukkomi in Japanese and straight-funny in English

Boke-tsukkomi is, as has been mentioned earlier, the typical verbal exchanges in Japanese stand-up comedy called manzai. The history of manzai dates back to the thirteenth century but the modern dialogue style of manzai is said to have started in the 1930 s. ${ }^{44}$

According to The Oxford English Dictionary 2nd ed., the word straight man seems to have appeared before $1923^{45}$ and the word funny man before $1861 .{ }^{46}$ Now we will look at the boke-tsukkomi and straight-funny exchanges respectively.

Analysis of boke-tsukkomi and straight-funny exchanges

\section{Example 1 (boke-tsukkomi)}

[Excerpt from the book "Nihon Bungakusha Hentairon: Bakushō Mondai (Japanese Literary People Perversion-ology)"] ${ }^{47}$

( $\mathrm{T}=$ Tanaka, the $t$ sukkomi; $\overline{\mathrm{O}}=\overline{\mathrm{O}} \mathrm{ta}$, the boke - They are talking about a pawnshop owner.)

1. T: Yoku shiruhito ni yoreba, mise ni iku to dare ga tenin de dare ga tenshu ka wakaranai hodo, shisso na minari o shiteita to iu.

= According to those who know him well, he dressed so simply when in his shop that you could not tell apart the owner from the clerks.

2. Ō: Hotondo, suppadaka datta rashii kara na.

= Always, he seemed to have been naked.

3. T: Tsukamaruyo!

$=$ He would get arrested!

Example 1 above shows how tsukkomi Tanaka and boke Ōta exchange their utterances. Line 2 and 3 form a boke-tsukkomi adjacency pair constituting incongruity - resolution. The social congruity can be deduced from line 1 that the pawnshop is

\footnotetext{
Katayama, op. cit., pp. 214-215.

45 Simpson \& Weiner (eds.), 'The Oxford English Dictionary 2nd ed. vol. XVI', p. 819.

46 Simpson \& Weiner (eds.), 'The Oxford English Dictionary 2nd ed. vol. VI', p. 273.

47 Bakushō Mondai, op. cit., p. 198.
} 
public and people are usually dressed in public, thus the pawnshop owner is just dressed in simple clothing. To this social congruity (i.e. the pawnshop owner is dressed in his shop) the boke line 2 (i.e. Always, he seemed to have been naked) is incongruent. The following tsukkomi line 3 (i.e. He would get arrested!) resolves this incongruity, forming IR, by adding the likely effect (i.e. getting arrested) of the cause (i.e. being naked in public) and this clinches the humorous exchange.

\section{Example 2 (straight-funny)}

[Excerpt from the book "Who's who in Comedy"] ${ }^{48}$

( $\mathrm{R}=$ Rossi, the straight man; $\mathrm{A}=$ Allen, the funny man - Rossi is playing an interviewer and Allen a boxer.)

1. R: What's your trickiest punch?

2. A: Left hook.

3. R: What's so tricky about that?

4. A: I use my right hand.

Example 2 above is a humorous dialogue between Rossi and Allen. Every line (i.e. line 1, 2, 3 and 4) is an integral part of this comic exchange, but line 1 and 3 can be regarded as typical to the straight man Rossi and line 2 and 4 to the funny man Allen. This is because, Rossi feeds Allen line 1 (i.e. What's your trickiest punch?) to elicit a part of the joke from him (i.e. Left hook), and Rossi feeds him again line 3 (i.e. What's so tricky about that?) to let him complete the joke by eliciting his final line (i.e. I use my right hand). This joke (i.e. he uses his right hand to deliver his left hook) is incongruent to the universal rule, i.e. humans cannot use their right hand to deliver their left hook. Allen is a human, and thus he cannot use his right hand to deliver his left hook. Upon hearing the final line (i.e. I use my right hand), most of the recipients should notice the incongruity, find it impossible and resolve it to constitute IR.

48 Smith, op. cit., p. 9. 


\section{Comparisons between boke-tsukkomi and straight-funny exchanges}

First of all, both boke-tsukkomi and straight-funny have setups in common, which will be described next by referring to the Fig 1 . Secondly, both texts shift from congruency to incongruency. In Ex. 1, until line 1(i.e. According to those who know him well, he dressed so simply when in his shop that you could not tell apart the owner from the clerks) the situation seems to be congruent with our common sense. But line 2 (i.e. Always, he seemed to have been naked) appears to be incongruent to what we usually think, i.e. shop clerks are usually dressed in the pawnshop. In Ex. 2, Allen's line 4 (i.e. I use my right hand) is incongruent to what we tend to assume from his previous line 2 (i.e. Left hook); he uses his left hand to deliver his left hook. And these incongruities are to be resolved to achieve IR.

However, while the boke-tsukkomi exchange in Ex. 1 shifts back to congruency with the tsukkomi line 3 (i.e. He would get arrested!), the straight-funny exchange in Ex. 2 does not. This is typical to boke-tsukkomi exchanges and the characteristic of tsukkomi as described earlier, talking sense to highlight the preceding non-sense line by boke.

\section{Setup}

The setup is 'the initial portion of text' composing a joke together with the second part punchline and the setup creates no incongruity but the punchline does. ${ }^{49}$ The setups of Ex. 1 and Ex. 2 will be illustrated by using the Funniness Structure Model (Fig. 1).

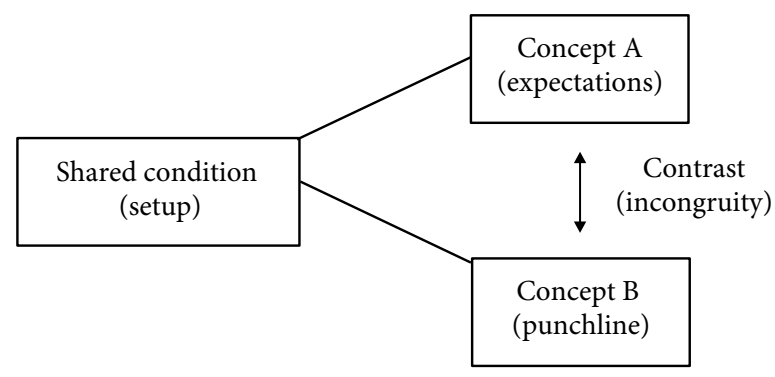

As seen above, 'expectations' and 'punchline' start from the same source 'setup', but contrast against each other to create 'incongruity'.

49 Ritchie, op. cit., p. 79. 
In Ex. 1, the setup is line 1 (i.e. According to those who know him well, he dressed so simply when in his shop that you could not tell apart the owner from the clerks). An example can be like He was very friendly to the clerks, however the punchline (i.e. Always, he seemed to have been naked) avoids such expectations. Those expectations and the punchline now make the incongruity.

In Ex. 2, the setup is line 1, 2 and 3 (i.e. R: What's your trickiest punch?, A: Left hook, R: What's so tricky about that?). An expectation can be like It is so fast, however the punchline (i.e. I use my right hand) betrays that expectation. Those expectations and punchline now create the incongruity.

Typically setups are provided by tsukkomi in the boke-tsukkomi exchanges and the straight man in the straight-funny exchanges. However, as seen in the funny man's line 2 in Ex. 2 (i.e. Left hook) which still constitutes the setup, the other part can also participate in setting up the joking material.

And also note that only the setup and the punchline appear on the surface but the expectations and the incongruity lie behind the lines. Since this is the case, we need to guess to some extent what the expectations and the ensuing incongruity would be in order to illustrate how the next boke-tsukkomi examples draw laughter.

\section{How the boke-tsukkomi exchange invites laughter}

We will now look at the transcribed audio-visual data. This approach will allow us to find laughables which immediately precede the laughter. ${ }^{50}$ Thus, if a boke line appears immediately before the laughter, the boke line will be identified as the laughable (cf. Ex. 3 below). Using this method, three examples will be looked into: 1) a boke laughable, 2) a tsukkomi laughable, 3) and a combination of boke and tsukkomi laughable. Parenthesised laughter: (laugh)/(LAUGH) are linked with the Romanised Japanese transcripts, not with the English translations. The role of tsukkomi, which is the only difference found between the boke-tsukkomi and straight-funny exchanges above, will be discussed in Ex. 3 .

50 Glenn, op. cit., p. 48. 


\section{Example 3 (boke laughable)}

[Excerpt from YouTube "U-ji Kōji 'Nyūgaku Shiken (high school entrance exam)"; $1: 46-1: 57 / 5: 57]^{51}$

( $\mathrm{M}=$ Mashiko, the boke; $\mathrm{F}=$ Fukuda, the tsukkomi; $\mathrm{A}=$ audience - Fukuda plays a student and Mashiko plays an exam monitor)

1. M: Hai, jā ano hajime dakara, chūijikō dake ne. Ano odo no derumon dage kittogu yōni ne, anō keitai denwa do, $=\mathrm{OK}$ then, to begin with, please turn off everything that makes a sound. Like mobiles,

2. F: $\bar{A}$.

$=$ Yes.

3. M: poketto beru do,

= pagers,

4. F: Iya, motteru yatsu inē be.

$=$ Well, I think nobody has them [= pagers $]$ anymore.

A: (laugh)

5. M: ado anō, kumayoge no suzu nanka mo hazushite oite ne.

$=$ and also bear deterrent bells, please take them off.

A:

(LAUGH)

6. F: Zettai motteru yatsu inē bena.

$=$ Definitely there's no one with one of them.

The laughter shown in capitals indicates being more intensified than the one in lower case. Therefore, (laugh) at line 4 is a minor laugh and (LAUGH) at line 5 is a major laugh.

At line 1 Mashiko starts the announcement (i.e. OK then, to begin with, please turn off everything that makes a sound), and then gives an example of such a device (i.e. Like mobiles). At line 2 Fukuda acknowledges it (i.e. Yes). These two lines are so

51 Owaraitv, 'Nyūgaku Shiken'. 
far within our expectations, hence no incongruity nor its resolution. However, at line 3 Mashiko gives another example (i.e. pagers) which is incongruous because they are not around anymore. If pagers were still around, the example would be congruous and the audience might not laugh. In response to this incongruous example, Fukuda at line 4 mumbles about it (i.e. Well, I think nobody has them [=pagers] anymore). This mumble brings the incongruous example to resolution, thus IR is clearly achieved before the audience. And since this mumble is immediately followed by the minor laugh at line $4 \mathrm{~A}$, it can be recognised as the minor laughable. Bear deterrent bells at line $5 \mathrm{M}$ are also an incongruous example because it is unlikely that 15 year-old students would bring them to their high school entrance exam. This incongruous example by the boke is laughable because the major laugh immediately follows it at line $5 \mathrm{~A}$. Although this incongruity is not explicitly resolved by the tsukkomi response before the laughter, resolution of the incongruity might be achieved by the audience themselves. During this short period between the utterance of the incongruous example and the laughter, it is expected that the audience realises that actually the students do not take the bells with them to their exam. In this way, IR seems to be achieved. The following tsukkomi line 6 (i.e. Definitely there's no one with one of them) gets no laughter. This indicates that this tsukkomi utterance is not meant to provoke laughter by resolving the boke's incongruity. It should be there as the unmoving second part of the conventionalized set boke and tsukkomi. Without this tsukkomi part, the dyadic exchange between the boke and tsukkomi will lack its rhythm and will not move on to the next smoothly.

\section{Example 4 (tsukkomi laughable)}

[Excerpt from YouTube “U-ji Kōji 'Tokoya (barber)”'; 0:15-0:22/ 5:49] ${ }^{52}$

( $\mathrm{F}=$ Fukuda, the tsukkomi; $\mathrm{M}=$ Mashiko, the boke; $\mathrm{A}=$ audience - They are talking about their concerns at a barber they go to for the first time. Mashiko has a crewcut.)

1. F: Sondemo ne yappa anō, hajimete iku tokoya ttsu nowā yappa chotto fuan ssu yone = Having said that, it is a bit scary to go to a barber you don't know, isn't it?

2. M: Fuan dayo nē are nē. Nanda ga omoidōri ni nannen janēka do omodde, sugē kowagu /nacchau/ ...

= Yeah, it's scary... Somehow I worry they won't cut it the way I want...(feeling his crewcut head with his hand)

52 Owaraitv, 'Tokoya'. 
3. F: Bōzu dakara kankē nē beyo!

= It wouldn't matter for a person with a crewcut!

A:

(LAUGH)

Fukuda at line $1 \mathrm{~F}$ launches the setup that people usually feel a bit scared about the result of the haircut at a barber they go to for the first time. Those people are meant to be those who have hair longer than a crewcut so that they tend to care about the haircut result. Since Mashiko has a crewcut, it is incongruous to be afraid of the result of his haircut even if at a barber he has never been to (cf. Line $2 \mathrm{M}$ ). This incongruity is explicitly resolved by the following tsukkomi at line $3 \mathrm{~F}$, constituting IR. This tsukkomi's resolution is then immediately followed by the laugh at line $3 \mathrm{~A}$, thus it is identified as the laughable.

\section{Example 5 (both boke and tsukkomi laughables)}

[Excerpt from YouTube “U-ji Kōji 'Tochigi Manzai 2"'; 1:48-2:01/ 3:51] ${ }^{53}$

( $\mathrm{M}=$ Mashiko, the boke; $\mathrm{F}=$ Fukuda, the tsukkomi; $\mathrm{A}=$ audience - After Mashiko gets too excited about their region called Kita Kantō, north of Tokyo, Fukuda asks if Mashiko has another topic unrelated to Kita Kantō. At line 1 Mashiko answers yes saying, 'Well, I do have other topics', and then looks like he is going to start talking about something else other than Kita Kantō)

1. M: Iya wadai aru yo iro iro. Ne, kyonen no kure desuka ne, yappa mada yabai nyūsu ga ne,

= Well, I do have other topics. Hey, we had horrible news the end of last year,

2. F: $\bar{A}$ ?

$=$ Yeah?

3. M: dō shimasu kore honto ni.

= What would you do about that really?

4. F: Nanka yabai nyūsu atta kke?

$=$ Did we have any horrible news?

5. M: Mada tobogede ome

= You gotta be kidding again.

53 Owaraitv, 'Tochigi Manzai 2'. 
6. F: Nani?

= What?

A: (laugh)

7. M: Kōsoku dōro no Kitakantō Jidōshadō ga kaitsū shichitta ppe na ome go rā! = The expressway called Kitakanto Expressway opened!

A: $\quad$ (LAUGH)

8. F: Mata Kita Kantō dabe yo!

$=$ Kita Kantō again!

A:

(LAUGH)

Boke line $7 \mathrm{M}$ is incongruous because the topic has not changed even though Mashiko at line $1 \mathrm{M}$ promises to change it. Since this boke line precedes the laugh at line $7 \mathrm{~A}$, it is identified as the laughable. Given this sequence of the incongruity and the laughter, it is assumed that this incongruity is resolved by the audience themselves, comprising IR, before their laughter. The following tsukkomi line $8 \mathrm{~F}$ explicitly resolves the incongruity, forming IR, and is also followed by laughter at line $8 \mathrm{~A}$. Thus tsukkomi line $8 \mathrm{~F}$ is the laughable as well. The incongruity that is resolved by the audience themselves and the following tsukkomi response is the same and it sounds like the tsukkomi's second resolution of the incongruity revives the laughter.

In summary, the laughable boke role goes off the track of the foregoing text and context to make a joke and both the laughable and non-laughable tsukkomi role brings the topic back on track to keep the comical dyadic exchange going on. In the next section, we will look in detail at how the tsukkomi role brings the topic back on track.

\section{Types of tsukkomi}

$\mathrm{Abe}^{54}$ claims that there are seven types of tsukkomi in two categories: 'call of attention' and 'comment on content'. 'Call of attention' only functions to draw the audience's attention to the boke line. This category includes 1) 'negation', 2) 'echo' and 3) 'silence'. 'Comment on content' literally adds comments on the boke line. This category includes 4) 'correction', 5) 'derivation', 6) 'metaphor' and 7) 'negative reflection'.

'Call of attention' in Ex. 6, 7 and 8.

$54 \quad$ Abe, op. cit., pp. 52-58. 


\section{Example 6 (negation)}

(Real-estate agent $\mathrm{A}$ attends customer B at his office)

1. A: Looking for a room?

2. B: Yeah.

3. A: Do you want to live in a student house or greenhouse?

4. B: Hey!

[Modified from YouTube "U-ji Kōji 'Fudōsanya (real-estate office)"'; $1: 32-1: 37 / 6: 09]^{55}$

Tsukkomi line 4 (i.e. Hey!) negates the preceding boke part (i.e. greenhouse). According to Abe, ${ }^{56}$ negation type, such as "Hey!" in this example, does not have much semantic meaning, but functions as a marker to call the audience's attention to the preceding boke line; as if to say offering a greenhouse to a customer to live in is absurd.

\section{Example 7 (echo)}

(Real-estate agent A attends customer B at his office)

1. B: (Opens the door) Hi, I'm looking for a room.

2. A: Oh, sorry we're out of pig huts.

3. B: Pig huts?

[Modified from YouTube "U-ji Kōji 'Fudōsanya (real-estate office)"'; $1: 11-1: 15 / 6: 09]^{57}$

Tsukkomi line 3 (i.e. pig huts?) echoes the incongruous part (i.e. pig huts) of the preceding boke line 2. Similar to the negation type, the echo type does not bear much semantic 
meaning of "pig huts", but it functions as a marker to call the audience's attention to the preceding boke part (i.e. pig huts). According to Abe, ${ }^{58}$ the echo type highlights the boke part unlike the negation type.

\section{Example 8 (silence)}

(A conversation between friends $\mathrm{A}$ and $\mathrm{B}$ )

1. A: I met this guy Mr. Green today.

2. B: Is he green?

3. A: (silence)

[Brought from the author's experience]

Tsukkomi line 3 keeps silent in response to the preceding boke line 2 (i.e. Is he green?). The silence type also does not show any explicit meaning, but it calls the audience's attention to the preceding boke line. The silence in response to a question will easily draw attention since the absence of the second part answer is usually dispreferred in question - answer adjacency pairs.

'Comment on content' in Ex. 9, 10, 11 and 12.

\section{Example 9 (correction)}

(College mate A greets another B)

1. A: Hey dude.

2. B: (sings) Hey dude, don't make it bad...

3. A: That's Jude!

[Brought from author's experience]

58 Abe, op. cit., p. 53. 
Tsukkomi line 3 corrects the incongruous part (i.e. dude) in the preceding boke line 2 by explicitly presenting the correct word (i.e. Jude) in the lyrics of the song Hey Jude. This correction type does not only draw the audience's attention to the preceding boke line, but also provides the audience with the correct answer (i.e. Jude).

\section{Example 10 (derivation)}

(Real-estate agent A takes his customer B to show a room)

1. A: Oh gosh, I forgot the key to the room.

2. B: Really?

3. A: Do you have a $10 \mathrm{c}$ coin?

4. B: Can it open it? What a room!

[Modified from YouTube "U-ji Kōji 'Fudōsanya (real-estate office)"'; 3:55-4:03/ 6:09 $]^{59}$

Tsukkomi line 4 (i.e. Can it open it? What a room!) derives from the preceding boke line 3 (i.e. Do you have a 10c coin?). This derivation type once accepts the preceding boke line, and then expands it into questions, comments and etc. as in line 4 (Can it open it? What a room!). By so doing, this derivation will illuminate how incongruous the boke line is, as if to say $10 \mathrm{c}$ coins should not be able to open the key to my new room.

\section{Example 11 (metaphor)}

(Real-estate agent A explains to his customer B how far the train station is from the house)

1. B: Is it close to the station?

2. A: Yeah, it only takes 3 minutes.

3. B: So it's like 100 meters, right?

59 Owaraitv, op. cit. 
4. A: No, it's 100 kilometers.

5. B: What am I, Superman?

[Modified from YouTube "U-ji Kōji 'Fudōsanya (real-estate office)"”; $1: 57-2: 05 / 6: 09]^{60}$

Tsukkomi line 5 is a metaphor (i.e. What am I, Superman?) out of the incongruity (i.e. a human being traveling $100 \mathrm{~km}$ in 3 minutes). The metaphor type also once accepts the preceding boke line, and then works out a metaphoric comment on it.

\section{Example 12 (negative reflection)}

1. A: Do you know Michael Jackson?

2. B: Yeah, Randy's brother, right?

3. A: No one remembers him that way!

[Modified from "Bakusho Mondai”] ${ }^{61}$

Tsukkomi line 3 (i.e. No one remembers him that way!) is a negative reflection on the preceding boke line (i.e. Yeah, Randy's brother, right?). That is to say, remembering Michael Jackson by his younger brother's name is incongruent to the normal assumptions that people associate him first with his popular numbers or unique dance routines (e.g. Thriller or moonwalk). Abe ${ }^{62}$ states that negative reflection type functions similarly to the negation type but they are different in that the former adds negative comment to the boke line but the latter does not.

Boke-tsukkomi exchange performed in English

Lastly, two examples of the boke-tsukkomi exchanges performed in English will be analysed and discussed in Ex. 13 and 14. 


\section{Example 13 (boke laughable)}

[Excerpt from YouTube "English Manzai"; 1:05-1:15/ 4:24] ${ }^{63}$

( $\mathrm{T}=$ Tsukkomi; $\mathrm{B}=$ Boke; $\mathrm{A}=$ audience $-\mathrm{The}$ tsukkomi and the boke just start off their manzai stand-up comedy.)

1. T: Good evening everyone. [Amm... We...]

A: [Good evening!]

2. T: Oh, thank you.

A: (laugh)

3. T: We came all the way from Japan.

4. B: [Yeah,] I'm so tired of swimming.
A: [Phwew!]
[(LAUGH)]

$\mathrm{T}$ :

[We didn’t swim!]

Boke line 4 is laughable as the laughter follows it. Setup line 3 (i.e. We came all the way from Japan) will make the audience imagine that they came by plane. But the punchline at line 4 (i.e. I'm so tired of swimming) betrays that expectation. Resolution of this incongruous punchline is considered to occur among the audience before their laughter to constitute IR. The following tsukkomi at line 4 (i.e. We didn't swim!) gets no laughter as it is swallowed by the laughter, but it completes its boke-tsukkomi unit. This tsukkomi is negative reflection type as it adds a negative comment on the preceding boke part.

\section{Example 14 (tsukkomi laughable)}

[Excerpt from YouTube "English Manzai"; 1:35-1:50/ 4:24] ${ }^{64}$

( $\mathrm{T}=$ Tsukkomi; $\mathrm{B}=$ Boke; $\mathrm{A}=$ audience - The tsukkomi suggests Two Idiots for their comedy duo name.) 
1. T: Um, what about, what about, umm, Two Idiots?

2. B: Hey, /the/ plagiarism is not good!

3. T: What! Plagiarism? It's not plagiarism. Why?

4. B: Two Idiots is the name of a bollywood movie, right?

5. T: That's 3 Idiots, you idiot!
6. A:
(LAUGH)

The audience might not be able to resolve the incongruity at boke line 4 (i.e. boke player's intentional false claim that Two Idiots is the title of an Indian film 3 Idiots), hence no laughter follows. On the other hand, tsukkomi line 5 (i.e. That's 3 Idiots, you idiot!) is laughable as it gets laughter at line 6. This tsukkomi line presents the correct name of the film, resolving the incongruity. Also putting down the boke player by saying 'you idiot' might bring out from the audience a sense of superiority over the boke player, inviting their laughter. This tsukkomi can be categorised as a correction type.

\section{Conclusion}

This paper has looked into the structure of boke-tsukkomi exchange and how it draws laughter. First of all, the tsukkomi role is found unique when comparing the structures of the boke-tsukkomi and the straight-funny exchanges. Further analyses of the boketsukkomi exchange confirm that the boke line makes jokes and the tsukkomi line makes a sharp response against the jokes. Secondly, this tsukkomi role could be dispensable in the boke-tsukkomi exchange to make the audience laugh but it seems to be necessary to keep the dyadic exchange moving on. Finally, although there is a language barrier, the boke-tsukkomi comedy can be translated into English and also invite laughter from an English speaking audience. In terms of the seven tsukkomi types, at least correction type is illustrated to be able to draw laughter in English (see Ex. 14). The other six types: negation, echo, silence, derivation, metaphor and negative reflection are yet to be examined in further research. It should be also interesting to take samples of the tsukkomi reactions to the boke's jokes across cultures and nations to find the similarities and differences. This is a fruitful topic for future research to discover cultural differences that appear in language-based humour. 
New Voices Volume 5

\section{Transcription symbols}

LAUGH capital letters indicate increased volume

(laugh) the position of (laugh) is linked with the Romanised Japanese transcript within the same turn

[ ] brackets indicate overlapping utterances

/ / the utterance within the two slashes indicates uncertainty in hearing

( ) the round brackets contain actions 


\section{References}

Abe, T., 'Manzai ni okeru "tsukkomi” no ruikei to sono hyōgen kōka', (Types and effect of "tsukkomi” in manzai), Kokugogaku kenkyū to shiryō, vol. 28, pp. 48-60. Retrieved 14 November 2010, from http://dspace.wul.waseda.ac.jp/dspace/bitstream/2065/29444/1/KokugogakuKenkyuToSiryo_28_Abe.pdf.

Aristotle, Poetics, trans. Fyfe, H. (London: Heinemann, 1927).

Attardo, S., Linguistic Theories of Humor (Berlin: Mouton de Gruyter, 1994).

Bakusho Mondai, Nihon Bungakusha Hentairon (Japanese Literary People Perversion-ology) (Tokyo: Gentosha, 2009).

Chiaro, D., The Language of Jokes: Analysing Verbal Play (Interface) (Oxon: Routledge, 1992).

Collins Pocket English Dictionary n.d. Retrieved 14 November 2010, from http://www.collinslanguage.com/results.aspx?context=3\&reversed=False\&action=define\&homonym=$1 \&$ text=stupid.

Critchley, S., On Humour: Thinking in Action (Oxon: Routledge, 2002).

Glenn, P., Laughter in Interaction (Cambridge: Cambridge University Press, 2003).

Grindsted, A., 'Joking As a Strategy in Spanish and Danish Negotiations' in Bargiela-Chiappini, F. and Harris, S. J. (eds.), The Languages of Business: An International Perspective (Edinburgh: Edinburgh University Press, 1997), pp. 159-182.

Inoue, H., Manzai: Osaka no warai (Manzai: Osakan Humor) (Kyoto: Sekai Shisōsha, 1981).

Integrative Arts 10 n.d., Who's on First. Retrieved 14 November 2010, from http://www.psu.edu/dept/inart10_110/inart10/whos.html.

Jagkanintesvenska, English Manzai. Retrieved 12 November 2010, from http://www.youtube.com/watch?v=Ygu5WPFsxvQ.

Jefferson, G., Notes on the Sequential Organization of Laughter in Conversation; Onset Sensitivity in Invitations to Laugh, Paper presented at the American Anthropological Association Convention, Mexico City (1974).

Jerfferson, G., Sacks, H. and Schegloff, E., 'Preliminary Notes on the Sequential Organization of Laughter', Pragmatics Microfiche (Cambridge: Cambridge University, Department of Linguistics, 1977). Retrieved 7 October 2011, from www.liso.ucsb.edu/Jefferson/Laughter_Prelim_Notes.pdf.

Katayama, H., 'Humor in Manzai Stand-up Comedy: A Historical and Comparative Analysis', The International Journal of the Humanities, vol. 6, no. 1, pp. 213-223. Retrieved 14 November 2010, from http://www.asianlang.mq.edu.au/japanese/documents/KatayamaHumorinManzaiStand-upComedy.pdf.

MacMillan Dictionary n.d.. Retrieved 14 November 2010, from http://www.macmillandictionary.com/dictionary/british/funny-man.

Martin, R. A., The Psychology of Humor: An Integrative Approach (Burlington: Elsevier Academic Press, 2007).

Merriam Webster n.d. Retrieved 14 November 2010, from http://www.merriam-webster.com/dictionary/straight\%20man.

Nilsen, A. P. and Nilsen, D. L. F., Encyclopedia of 20th-century American Humor (Phoenix: The Oryx Press, 2000). 
New Voices Volume 5

Norrick, N. R., Conversational Joking: Humor in Everyday Talk (Bloomington: Indiana University Press, 1993).

Ōshima, K., 'Rakugo and Humor in Japanese Interpersonal Communication', in Davis, J. M. (ed.), Understanding Humor in Japan (Detroit: Wayne State University Press, 2006), pp. 99-109.

Owaraitv, Owarai: U-ji Kōji "Nyūgaku Shiken (high school entrance exam)". Retrieved 12 November 2010, from http://www.youtube.com/watch?v=UkdhHnE4ynI\&feature=fvw.

Owaraitv, U-ji Kōji “Fudōsanya (real-estate office)”. Retrieved 12 November 2010, from http://www.youtube.com/watch?v=Fz67xW0QiWI.

Owaraitv, U-ji Kōji “Tochigi Manzai 2”. Retrieved 12 November 2010, from http://www.youtube.com/watch?v=bPKKF9r_LqE.

Owaraitv, U-ji Kōji “Tokoya (barber)”. Retrieved 12 November 2010, from http://www.youtube.com/watch? $v=q d j Z t l Z A y c o \& f e a t u r e=f v s r$.

Partington, A., The Linguistics of Laughter: A Corpus-Assisted Study of Laughter-Talk (Oxon: Routledge, 2006).

Provine, R. R., Laughter: A Scientific Investigation (New York: Viking, 2000).

Provine, R. R. and Fischer, K. R., 'Laughing, Smiling, and Talking: Relation to Sleeping and Social Context in Humans', Ethology, vol. 83, no. 4 (1989), pp. 295-305.

Raskin, V., Semantic Mechanisms of Humor (Dordrecht: Reidel Publishing Company, 1985).

Ritchie, G., 'Developing the Incongruity-Resolution Theory', Proceedings of the AISB 99 symposium on creative language: humour and stories, pp. 78-85. Retrieved 14 November 2010, from http://citeseerx.ist.psu.edu/viewdoc/download?doi=10.1.1.136.4937\&rep=rep1\&type=pdf.

Sacks, H., 'An Analysis of the Course of A Joke's Telling in Conversation', in Bauman, R. and Sherzer, J. (eds.), Explorations in the Ethnography of Speaking (London; Cambridge University Press, 1974), pp. 337-353.

Schegloff, E., 'Sequencing in Conversational Openings', in Gumperz, J. and Hymes, D. (eds.), Directions in Sociolinguistics (New York: Holt, Rinehart and Winston, 1972a), pp. 346-380.

Schegloff, E. and Sacks, H., 'Opening Up Closings', Semiotica, vol. 7, no. 4 (1973), pp. 289-327.

Schenkein, J., 'Towards an Analysis of Natural Conversation and the Sense of Heheh', Semiotica, vol. 6, no. 4 (1972), pp. 344-377.

Schiffrin, D., Approaches to Discourse (Massachusetts: Blackwell Publishers, 1994).

Shultz, T. R., 'A Cognitive-Developmental Analysis of Humour', in Chapman, A. J. and Foot, H. C. (eds.), Humor and Laughter: Theory, Research, and Applications (New Brunswick, New Jersey: Transaction Publishers, 1976), pp. 11-36.

Simpson, J. A. and Weiner, E. S. C. (eds.), The Oxford English Dictionary 2nd ed., vol. VI (Oxford: Oxford University Press, 1989).

Simpson, J. A. and Weiner, E. S. C. (eds.), The Oxford English Dictionary 2nd ed., vol. XVI (Oxford: Oxford University Press, 1989).

Smith, R., Who's who in Comedy (New York: Facts on File, 1992). 
Hideo Tsutsumi

Sperber, D. and Wilson, D., Relevance: Communication and Cognition 2nd ed. (Oxford: Blackwell Publishers Ltd, 1995).

Stocker, J. F., 'Manzai: Team Comedy in Japan's Entertainment Industry', in Davis, J. M. (ed.), Understanding Humor in Japan (Detroit: Wayne State University Press, 2006), pp. 51-74.

Wardhaugh, R., An Introduction to Sociolinguistics 4th ed. (Massachusetts: Blackwell Publishing Ltd, 1986). 